\title{
Effects of Repeated Administration of Pentazocine on Ambulatory Activity in Mice: Comparison with the Effects of Morphine and Methamphetamine
}

\author{
Suguru FUJIWARA ${ }^{1,2}$, Hisashi KURIBARA ${ }^{1, *}$ and Sakutaro TADOKORO ${ }^{1}$ \\ ${ }^{1}$ Division for Behavior Analysis, Behavior Research Institute, \\ Gunma University School of Medicine, 3-39-22 Showa-machi, Maebashi 371, Japan \\ ${ }^{2}$ Biochemical Research Laboratory, Morinaga Milk Ind. Co.. \\ 5-1-83 Higashihara, Zama 228. Japan
}

Accepted June 1, 1990

\begin{abstract}
Effects of single and repeated administration of pentazocine (5 times at intervals of 3-4 days) were compared with those of morphine and methamphetamine by means of ambulatory activity in mice. The interactions among these 3 drugs were also investigated. Pentazocine (25 mg/kg. s.c.). morphine $\langle 10$ and $20 \mathrm{mg} / \mathrm{kg}$. s.c.) and methamphetamine (2 $\mathrm{mg} / \mathrm{kg}$. s.c.) significantly increased the activity, and the effect progressively enhanced (defined here as development of reverse tolerance) during the repeated administration schedule. The induction of reverse tolerance to pentazocine was less dependent on the environmental conditions, and it was abolished within 2 months. A cross reverse tolerance was demonstrated from methamphetamine to pentazocine and to morphine, and from morphine to pentazocine. However, no significant cross reverse tolerance was induced from pentazocine to morphine and to methamphetamine, and from morphine to methamphetamine. The present results suggest that pentazocine possesses an ambulation-increasing effect, although the characteristics are different from that of either morphine or methamphetamine.
\end{abstract}

Pentazocine, a benzomorphan derivative, is a mixed opiate agonist-antagonist, and this drug has been widely used in clinical therapy as an analgesic. Recently, however, some problems, including psychotomimetic effects, have been pointed out (1-3). Pentazocine has been considered to have actions on dopamine receptors as well as opiate receptors $(4,5)$.

On the other hand, both morphine, an opiate agonist, and methamphetamine, an indirect agonist on dopamine receptors, increase the ambulatory activity of mice; and an enhancement of the ambulation-increasing effect, defined here as reverse tolerance, is elicited when these drugs are repeatedly administered at intervals of longer than 1 day $(6,7)$. However, these experiments also indicated that the methamphetamine- and

* To whom all correspondence shoula be addressed. morphine-induced reverse tolerances were partially different in their characteristics. Furthermore, it has been demonstrated that a cross reverse tolerance from methamphetamine to morphine is easily produced, but hardly produced from methamphetamine to morphine (8).

The characteristics of the behavior-stimulant effect of pentazocine have been insufficiently investigated, although it possesses actions on the dopamine systems $(4,5)$. Hence, the purposes of this experiment were to study the effects of single and repeated administration of pentazocine by means of ambulatory activity in mice, and the effects were compared with those of morphine and methamphetamine. In addition. interactions among these 3 drugs were also investigated.

\section{Materials and Methods}

Animals 
Male ddY strain mice (Japan Laboratory Animal) were used at the age of 7 weeks and the weight of 28-35 g. During the experimental period, the illumination (light period: 6 a.m. -6 p.m.) and temperature $\left(22 \pm 2^{\circ} \mathrm{C}\right)$ of the breeding room were controlled.

\section{Drugs}

The drugs used were pentazocine (Pentagin Inj. ${ }^{\otimes}$ : Sankyo Pharm.), morphine $\mathrm{HCl}$ (Takeda Chem.) and methamphetamine $\mathrm{HCl}$ (Dainippon Pharm.). These drugs were dissolved in or diluted by physiological saline and administered subcutaneously (s.c.) at a fixed volume of $0.1 \mathrm{ml} / 10 \mathrm{~g}$ body weight of the mouse regardless of the drug doses.

\section{Ambulation measurement}

The ambulatory activity of a mouse was measured by a tilting-type ambulometer (AMB-10. O'Hara \& Co.). Ten mice were individually put into activity cages; and after an adaptation period of $30 \mathrm{~min}$, the drug administration was conducted. The ambulatory activity of each mouse was measured for $3 \mathrm{hr}$ after the drug administration.

Repeated administration schedules: Mice were treated with either pentazocine $(6.25$ or $25 \mathrm{mg} / \mathrm{kg}$ ). morphine (10 or $20 \mathrm{mg} / \mathrm{kg}$ ). methamphetamine $(2 \mathrm{mg} / \mathrm{kg})$ or saline 5 times at intervals of 3-4 days.

Four days after the 5 th drug injection, the following drug administrations were conducted: 1) One group of mice that had experienced 5 times administration of pentazocine (25 mg/kg) had been kept for 2 months without any treatment. Then, they were readministered the same dose of pentazocine. 2) Cross administration of pentazocine $(25 \mathrm{mg} /$ $\mathrm{kg}$ ) was conducted in mice that had experienced either saline, morphine (10 and 20 $\mathrm{mg} / \mathrm{kg}$ ) or methamphetamine $(2 \mathrm{mg} / \mathrm{kg}) .3$ ) Cross administration of morphine $(20 \mathrm{mg} / \mathrm{kg})$ was conducted in mice that had experienced either saline, pentazocine $(6.25$ and $25 \mathrm{mg} /$ $\mathrm{kg}$ ) or methamphetamine (2 $\mathrm{mg} / \mathrm{kg})$. 4) Cross administration of methamphetamine $(2 \mathrm{mg} /$ $\mathrm{kg})$ was conducted in mice that had experienced either saline, pentazocine $(6.25$ and $25 \mathrm{mg} / \mathrm{kg}$ ) or morphine (10 and $20 \mathrm{mg} / \mathrm{kg}$ ). The administration of pentazocine, morphine and methamphetamine, at the doses equivalent with those injected in the cross administration schedule, were also carried out in the drug-naive and age-adjusted mice.

Repeated pentazocine treatment in a small jar: Mice were treated with pentazocine (25 $\mathrm{mg} / \mathrm{kg}$ ) or saline 4 times at intervals of 3-4 days, and they were individually put into small glass jars (5.5-cm in diameter) for $3 \mathrm{hr}$. In the jar, the mouse's ambulatory movement was perfectly restricted. Four days after the 4 th administration, these mice were given pentazocine $(25 \mathrm{mg} / \mathrm{kg})$ in the activity cage.

The doses of morphine and methamphetamine and the number and intervals of their repeated administration were considered to be optimum according to our previous studies $(6-8)$.

The experiment of the ambulatory activity measurement was held between 10 a.m. -5 p.m. In each experiment, 16-20 mice were used.

\section{Statistical analysis}

The overall variance of the mean ambulatory activity counts for $3 \mathrm{hr}$ were analyzed. In a case of significant variance. Student's $t$ test and/or the Cochran-Cox test were applied to compare mean values. When $P$ values were equal to or less than 0.05 , they were defined to be significantly different.

\section{Results}

Figure 1 shows the temporal changes in mean ambulatory activity counts after administration of saline. pentazocine $(6.25$ and $25 \mathrm{mg} / \mathrm{kg}$ ), morphine (10 and $20 \mathrm{mg} / \mathrm{kg}$ ) and methamphetamine $(2 \mathrm{mg} / \mathrm{kg}$ ) to the drug-naive mice. Pentazocine scarcely changes the ambulatory activity at $6.25 \mathrm{mg} /$ $\mathrm{kg}$, but markedly increased it at $25 \mathrm{mg} / \mathrm{kg}$. The ambulation-increasing effect attained its maximum level at $20-30 \mathrm{~min}$ and persisted for about $1 \mathrm{hr}$. Morphine and methamphetamine increased the activity with the maximum effect at $30-40 \mathrm{~min}$ and duration for longer than $2 \mathrm{hr}$ after the administration.

Figure 2 shows the mean overall ambulatory activity counts for $3 \mathrm{hr}$ after the repeated 5 times administration of saline, pentazocine $(6.25$ and $25 \mathrm{mg} / \mathrm{kg}$ ). morphine (10 and 20 $\mathrm{mg} / \mathrm{kg}$ ) and methamphetamine $(2 \mathrm{mg} / \mathrm{kg}$ ). The ambulatory activity counts slightly but significantly decreased when saline was repeatedly administered. The repeated administration of pentazocine $(6.25 \mathrm{mg} / \mathrm{kg})$ 

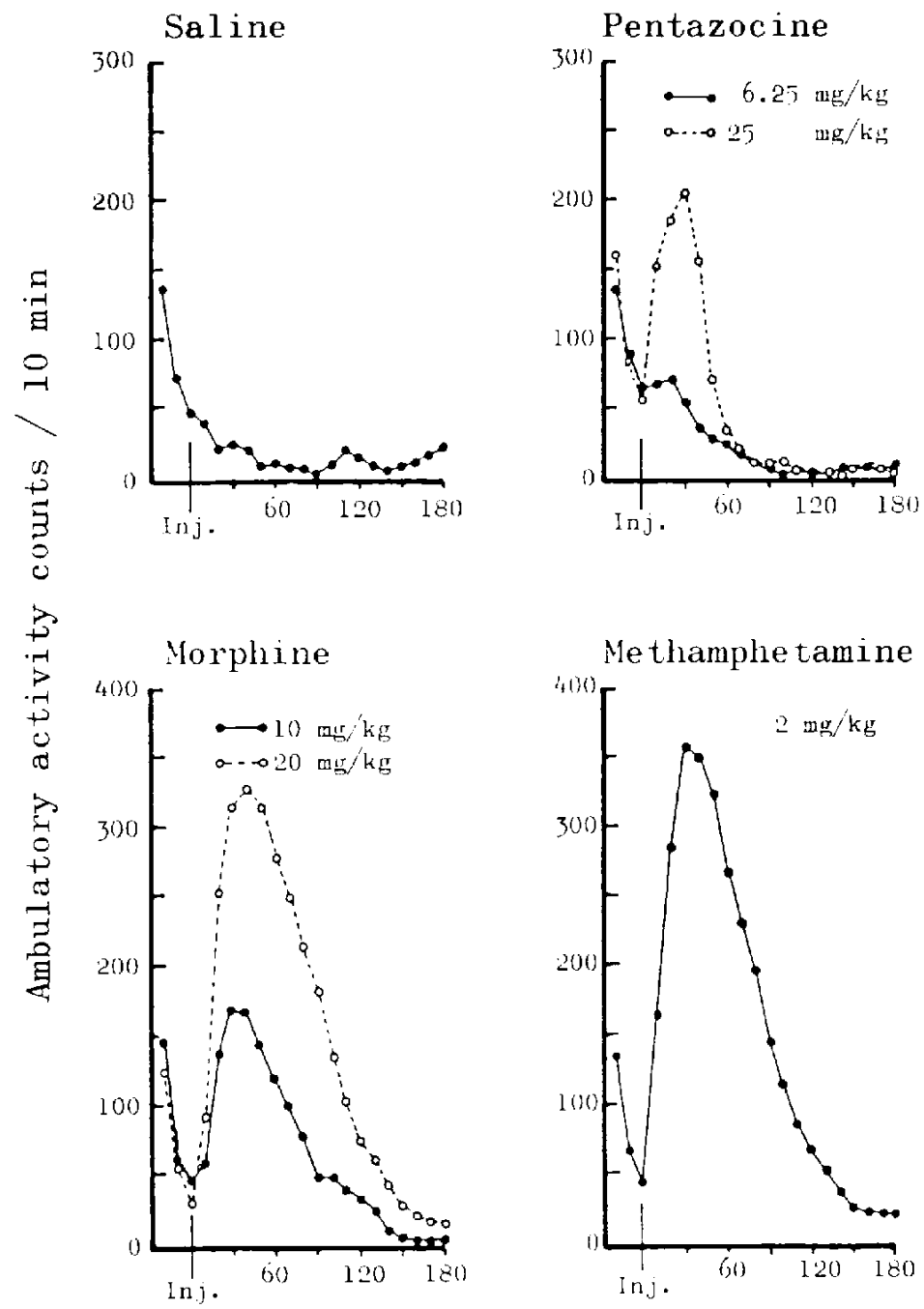

Time after drug administration (min)

Fig. 1. Temporal changes in ambulatory activity counts after administration of saline, pentazocine $(6.25$ and $25 \mathrm{mg} / \mathrm{kg}$ ), morphine (10 and $20 \mathrm{mg} / \mathrm{kg}$ ) and methamphetamine $(2 \mathrm{mg} / \mathrm{kg})$ to the drug-naive mice. Each drug dose or saline was administered subcutaneously (s.c.) after an adaptation period of $30 \mathrm{~min}$ for the activity cage, and cumulative activity counts during 10 min segments were recorded for 3 hr thereafter. Numbers of mice used were 30 in the saline-, pentazocine- and morphine-administered groups and 20 in the methamphetamine-administered groups.

caused no marked change in the activity counts throughout the repeated administration. However, the repeated administration of pentazocine $(25 \mathrm{mg} / \mathrm{kg})$, morphine $(20 \mathrm{mg} /$ $\mathrm{kg}$ ) and methamphetamine $(2 \mathrm{mg} / \mathrm{kg}$ ) elicited a progressive enhancement of their ambulation-increasing effect. The ambulation-increasing effect of morphine $(10 \mathrm{mg} / \mathrm{kg})$ also increased during the repeated administration. although such a change did not reach a significant level.

In addition, a few mice that were treated with pentazocine $(25 \mathrm{mg} / \mathrm{kg})$ exhibited a convulsion in the 3rd and later administration, in spite of showing no convulsion in the $1 \mathrm{st}$ and 2 nd administration (data not shown). 

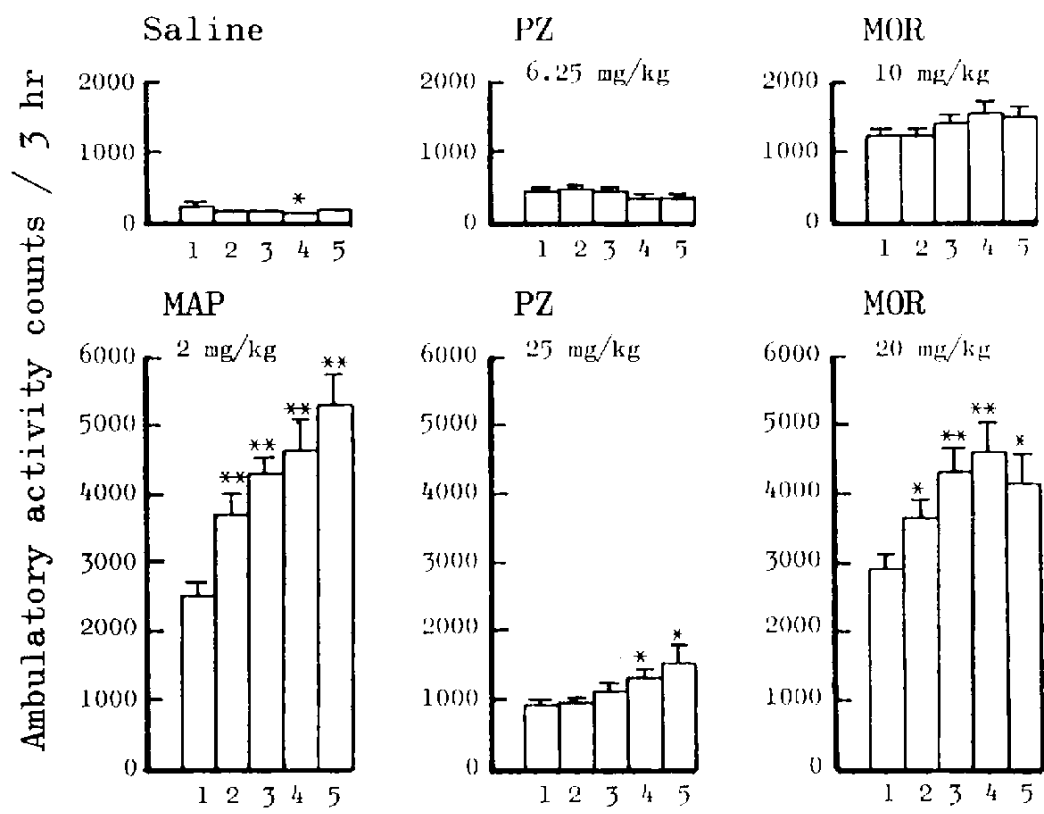

$\mathrm{PZ}$

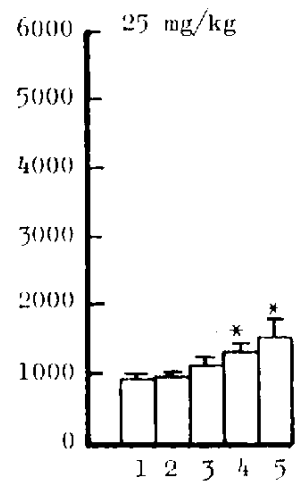

MOR

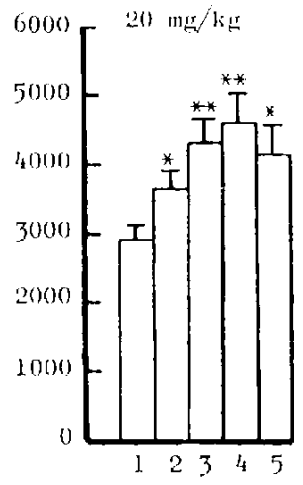

Number of drug administration

Fig. 2. Mean overall ambulatory activity counts for $3 \mathrm{hr}$ after the repeated 5 times administration of saline, pentazocine (PZ: 6.25 and $25 \mathrm{mg} / \mathrm{kg}$. s.c.), morphine (MOR: 10 and $20 \mathrm{mg} / \mathrm{kg}$. s.c.) and methamphetamine (MAP: $2 \mathrm{mg} / \mathrm{kg}$. s.c.) at intervals of 3-4 days. "and ** indicate a significant difference from the value in the corresponding 1 st administration ( $P<0.05$ and 0.01 , respectively). Numbers of the mice used were the same as those presented in the Fig. 1 legend.

The reverse tolerance to the ambulationincreasing effect of pentazocine was almost completely abolished by 2 months after the cessation (data not shown).

Figure 3 shows the data obtained in the cross administration schedules. There was no significant difference in the activity counts between the drug-naive and saline-experienced mice after administration of pentazocine, morphine and methamphetamine. When pentazocine $(25 \mathrm{mg} / \mathrm{kg})$ was crossadministered to the morphine- and methamphetamine-experienced mice, they demonstrated significantly higher activity counts than the saline-experienced mice (upper panel). Methamphetamine-experienced mice, but not pentazocine-experienced mice. showed an increased sensitivity to the ambulation-increasing effect of morphine $(20 \mathrm{mg} /$ $\mathrm{kg}$ ) (middle panel). On the other hand, neither pentazocine-experienced mice nor morphine-experienced mice exhibited a significant increase in the sensitivity to the ambulation-increasing effect of methamphetamine (2 $\mathrm{mg} / \mathrm{kg}$ ) (lower panel).

Figure 4 shows mean overall ambulatory activity counts for $3 \mathrm{hr}$ after administration of pentazocine $(25 \mathrm{mg} / \mathrm{kg})$ to the mice that had been treated with pentazocine or saline in the small glass jar. The repeated treatment with pentazocine in the small jar induced a reverse tolerance to its ambulation-increasing effect. Thus, the mean overall ambulatory activity counts were almost identical in the groups of mice that had experienced pentazocine in the activity cage and the small glass jar.

\section{Discussion}

The present experiment demonstrated that a comparatively higher dose of pentazocine (i.e., $25 \mathrm{mg} / \mathrm{kg}$ ) increased the mouse's ambulatory activity. It has been considered that pentazocine acts as an antagonist on the mureceptor site, but acts as an agonist on the kappa- and sigma-receptor sites (9). It has been also shown that opioid-induced hyper- 

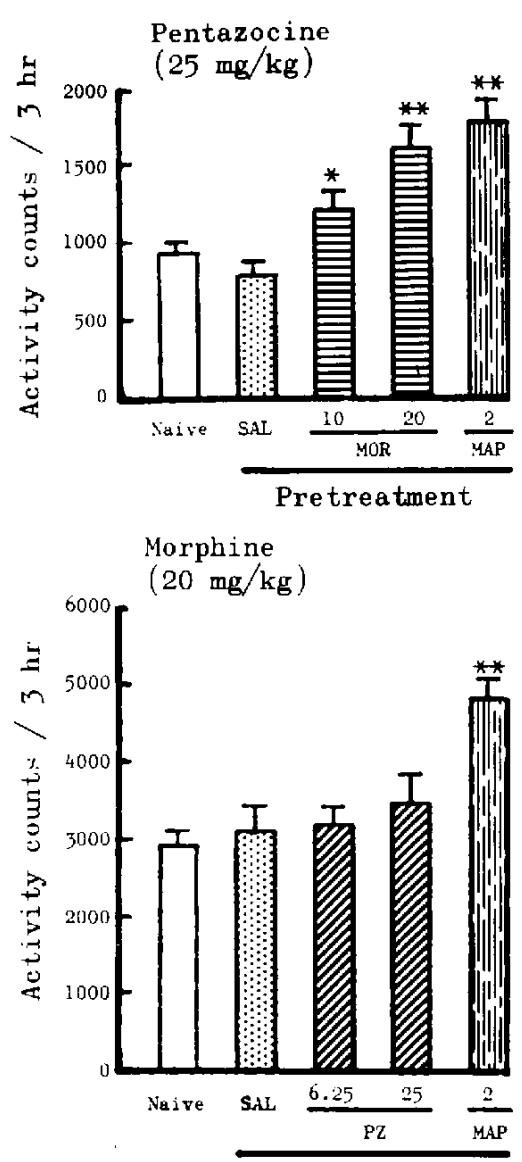

Pretreatment

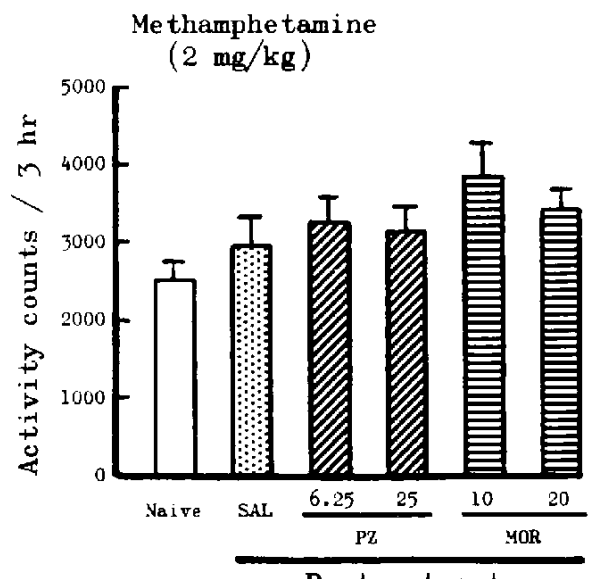

Pretreatment

Fig. 3. Mean overall ambulatory activity counts for $3 \mathrm{hr}$ after the cross administration of drugs. Upper panel: Administration of pentazocine $(25 \mathrm{mg} / \mathrm{kg}$. s.c.) to the mice that had experienced saline (SAL: s.c.). morphine (MOR: 10 and $20 \mathrm{mg} / \mathrm{kg}$. s.c.) or $f$ activity originates through agonistic action on the mu- and sigma-receptor sites (10). Furthermore, pentazocine has been reported to possess a direct agonistic action on dopamine receptors $(4,5)$. It is therefore considered that opiate systems as well as dopa-

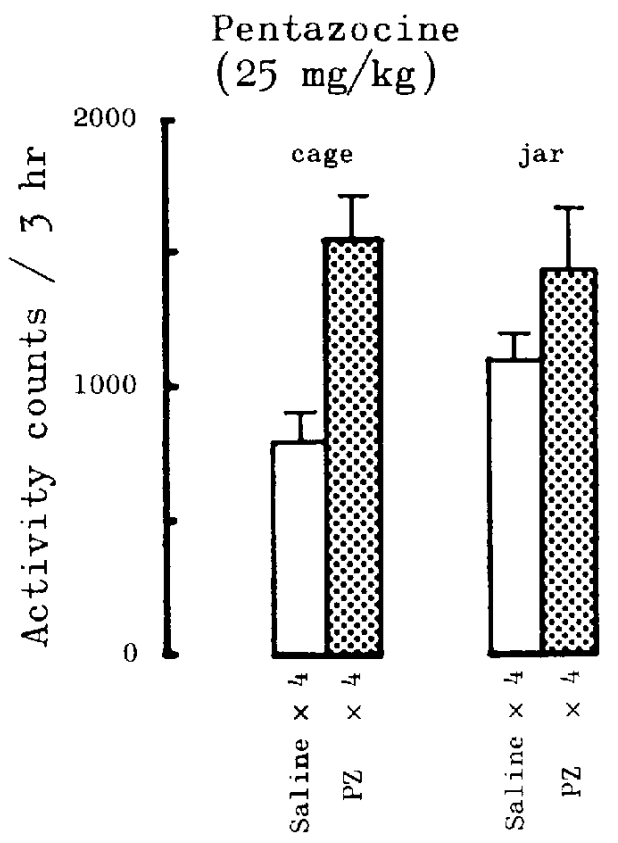

Fig. 4. Mean overall ambulatory activity counts for $3 \mathrm{hr}$ after administration of pentazocine $(25 \mathrm{mg} /$ $\mathrm{kg}$. s.c.) to the mice that had experienced saline or the same dose of pentazocine 4 times at intervals of 3-4 days in the activity cage $(25 \mathrm{~cm}$ in diameter) or in a glass jar $(5.5 \mathrm{~cm}$ in diameter) for $3 \mathrm{hr}$ each. Number of mice used were 20 in each group.

¿methamphetamine (MAP: $2 \mathrm{mg} / \mathrm{kg}$, s.c.) 5 times at intervals of 3-4 days. Middle panel: Administration of morphine (20 $\mathrm{mg} / \mathrm{kg}$. s.c.) to the mice that had experienced saline, pentazocine ( $P Z: 6.25$ and 25 $\mathrm{mg} / \mathrm{kg}$. s.c.) or methamphetamine (2 $\mathrm{mg} / \mathrm{kg}$. s.c.) 5 times at intervals of 3-4 days. Lower panel: Administration of methamphetamine ( $2 \mathrm{mg} / \mathrm{kg}$, s.c.) to the mice that had experienced saline, pentazocine $(6.25$ and $25 \mathrm{mg} / \mathrm{kg}$. s.c.) or morphine (10 and $20 \mathrm{mg} / \mathrm{kg}$. s.c.) 5 times at intervals of 3-4 days. The results after the administration of pentazocine, morphine and methamphetamine to the drug-naive mice are also presented in the corresponding panels. Number of mice used were 16-30 in each experiment. " and **: Significantly different from the saline-experienced mice ( $P<0.05$ and 0.01 , respectively). 
mine systems are involved in the pentazocineinduced increase in the ambulatory activity in mice. On the other hand, the hyperactivity induced by morphine and methamphetamine has been reported to be mainly due to the following mechanisms: Morphine indirectly stimulates catecholaminergic systems through an agonistic action on opiate systems, in particular the mu-receptor site (11-13). Methamphetamine indirectly stimulates catecholaminergic systems through facilitation of the release as well as inhibition of reuptake of the neurotransmitters (14).

The present experiment revealed that the repeated administration of pentazocine induced a reverse tolerance to its ambulationincreasing effect in mice. This result is similar to that reported in rats (15). Such an enhancement of the effect is hardly attributable to an accumulation of pentazocine. This is not only because administered pentazocine is almost completely metabolized in the liver and excreted in the urine with a plasma half-life of 2-3 hr (9), but because the repeated administration of the small dose $(6.25 \mathrm{mg} / \mathrm{kg})$ produced no marked change in the activity throughout the administration schedule. It is therefore reasonable to consider that the enhancement of the effect of pentazocine is induced through a mechanism that is partially similar to those involved in the reverse tolerance to the ambulation-increasing effect of morphine (7) and methamphetamine (6. 16). Since the reverse tolerance to methamphetamine in animals is closely related with amphetamine psychosis in humans (17). there is also a possibility that the reverse tolerance to pentazocine is related to the development of psychotomimetic symptoms during chronic use of pentazocine (1-3)

The development of cross reverse tolerance was dependent on the drug combinations. Thus, an increased sensitivity to pentazocine was induced in the methamphetamine-experienced mice. However, the pentazocineexperienced mice demonstrated no significant change in the sensitivity to methamphetamine. These characteristics of the interaction between pentazocine and methamphetamine are similar to those between morphine and methamphetamine as demonstrated in this and previous experiments (8). However, the pentazocine-experienced mice failed to exhibit any cross reverse tolerance to morphine. although the morphine-experienced mice showed an increased sensitivity to pentazocine. This finding suggests that the behavioral characteristics of pentazocine are different from those of either morphine or methamphetamine when the mouse's ambulatory activity is used as the indicator of the drug effects. Sansone et al. (18) also showed that the pentazocine-induced hyperactivity in mice was not specifically related to opioid mechanisms. It is difficult to elucidate the detailed mechanism involved in the cross reverse tolerances observed in the present experiment. However, there is a possibility that the mice were able to discriminate between the effects of these 3 drugs.

The difference of the characteristics between the reverse tolerance to pentazocine and those to methamphetamine and morphine can be demonstrated by the following findings. The reverse tolerance to pentazocine was induced in the mice that had experienced the drug in either the activity cage or the small jar, indicating that the effect was independent of the environmental condition. In addition, the established reverse tolerance to pentazocine is almost reversible. The reverse tolerance to the ambulation-increasing effect of methamphetamine and morphine could be induced in a freely movable situation $(6,7)$. Furthermore, the reverse tolerance to methamphetamine once established was perfectly irreversible (6). The reverse-tolerance to morphine was reversible, but an increased sensitivity was partially maintained for longer than 2 months (7). The differences among the 3 drugs might be due to pentazocine's ability to directly act on both opiate and dopamine systems $(4,5,9,10)$. However, a further experiment is required to determine what mechanism is dominant in the ambulationincreasing effect of pentazocine.

\section{References}

1 Goldstein, G.: Pentazocine. Drug Alcohol Depend. 14, 313-324 (1985)

2 Kazamatsuri, M. and Nakagome, K.: Psychiatric complications of medical drugs. Japan. J. Neuropsychopharmacol. 10, 5-24 (1988) (in Japanese) 
3 Matsushita, M.: Psychiatric complications of pentazocine. Japan. J. Neuropsychopharmacol 10,77-87 (1988) (in Japanese)

4 Hernandez, L.L. and Appel, J.B.: Dopaminergic involvement in the mechanism of action of pentazocine. Behav. Neural Biol. 26, 384-400 (1979)

5 Hernandez, L.L. and Appel, J.B.: Effect of pentazocine and other oplates on shock detection in the rat: Involvement of opiate and dopamine receptors. Psychopharmacology (Berlin) 67, 155-163 (1980)

6 Hirabayashi, M. and Alam, M.R.: Enhancing effect of methamphetamine on ambulatory activity produced by repeated administration in mice. Pharmacol. Biochem. Behav. 15, 925932 (1981)

7 lizuka, M. and Hirabayashi, M.: Enhancing effect of morphine on ambulatory activity produced by repeated administration in mice. Folia Pharmacol. Japon. 82, 293-301 (1983) (Abs. in English)

8 Kuribara, $\mathrm{H}$. and Tadokoro, S.: Reverse tolerance to ambulation-increasing effects of methamphetamine arid morphine in 6 mouse strains. Japan. J. Pharmacol. 49, 197-203 (1989)

9 Jaffe, J.H. and Martin, W.R.: Opioid analgesics and antagonists. In The Pharmacological Basis of Therapeutics, 7th edition, Edited by Gilman. A.G., Goodman, L.S., Rall, T.W. and Murod, F., p. 491-531. MacMillan Pub. New York (1985)

10 Iwamoto, E.T.: Locomotor activity and antinociception after putative mu, kappa and sigma opioid receptor agonists in the rat: Influence of dopaminergic agonists and antagonists. J. Pharmacol. Exp. Ther. 217, 451-460 (1981)

11 Rethy, C.R., Smith, C.B. and Villarreal, J.E.:
Effects of narcotic analgesics upon the locomotor activity and brain catecholamine content of the mouse. J. Pharmacol. Exp. Ther. 176, 472-479 (1971)

12 Buxbaum, D.M., Yarbough, G.G. and Garter, M.E.: Biogenic amine and narcotic effects. I. Modification of morphine-induced analgesis and motor activity after alteration of catecholamine levels. J. Pharmacol. Exp. Ther. 185, 317327 (1973)

13 Kuschinsky, K. and Hornykiewics, O.: Effects of morphine on striatal dopamine metabolism: Possible mechanism of its opposite effect on locomoter activity in rats and mice. Eur. J. Pharmacol. 26, 41-50 (1988)

14 Fischman, M.W.: Cocaine and the amphetamines. in Psychopharmacology: The Third Generation of Progress, Edited by Meltzer, H.Y., p. 15431553, Raven Press, New York (1987)

15 Davis, W.M., Hemnani, K.L. and Pace, H.B.: Motility response of rats to chroric constantdose treatment with narcotics. Pharmacol. Biochem. Behav. 17, 489-494 (1982)

16 Kuribara, $H$. and Hirabayashi, M.: Reverse tolerance to psychotropic drugs. Japan. J. Neuropsychopharmacol. 7, 421-439 (1985) (in Japanese)

17 Tadokoro, S. and Kuribara, $\mathrm{H}$.: Reverse tolerance to the ambulation increasing effect of methamphetamine in nice as an animal model of amphetamine psychosis. Psychopharmacol. Bull. 22. 757-762. (1987)

18 Sansone, M., Castellano, $C$. and Libri, V.: Tripelennamine enhances buprenorphine- but not pentazocine-induced hyperactivity in mice. Psychopharmacology (Berlin) 95, 176-179 (1988) 